\title{
Crop Production, Livestock Production and Economic Growth in Botswana (1990-2017): An Application of ARDL Model
}

\author{
Mufaro Andrew Matandare ${ }^{1, a^{*}}$, Patricia Masego Makepe ${ }^{2, b}$, \\ Lekgatlhamang Setlhare $^{1, \mathrm{c}}$, Jonah Bajaki Tlhalefang ${ }^{1, \mathrm{~d}}$ \\ ${ }^{1}$ Faculty of Social Sciences, Economics Department, University of Botswana, P. Bag UBo022, Gaborone, Botswana
${ }^{2}$ Center for Business Management and Entrepreneurship; and General Education, Botswana International University of Science and
Technology, P. Bag 16, Palapye, Botswana \\ * Corresponding author
}

\begin{tabular}{|c|c|}
\hline A R T I C L E I N F O & A B S T R A C T \\
\hline $\begin{array}{l}\text { Keywords: } \\
\text { Crop production } \\
\text { Livestock production } \\
\text { Economic growth } \\
\text { Botswana } \\
\text { ARDL }\end{array}$ & $\begin{array}{l}\text { There are few studies in Botswana which have examined the relationship between agriculture and } \\
\text { economic growth. The uniqueness of this study is grounded in investigating disintegrated agriculture } \\
\text { components into crop production and livestock production and investigating their nexus with economic } \\
\text { growth. This study estimated the short and long term effects between crop production, livestock } \\
\text { production and economic growth in Botswana for the period } 1990 \text { to } 2017 \text {. The Auto-Regressive } \\
\text { Distributed Lagged (ARDL) bounds testing approach was employed to investigate the stated relationship. } \\
\text { Study findings from the ARDL bound testing approach confirm evidence of a long-run equilibrium } \\
\text { relationship between crop production, livestock production and economic growth. Results indicated that } \\
\text { livestock production has a positive and significant impact on economic growth both in the short run and } \\
\text { long run. On the other hand crop production has a positive and significant impact on economic growth } \\
\text { only in the long run. Efforts towards supporting agricultural sector growth should be emphasized to } \\
\text { promote agricultural sector productivity in a bid to forge a move away from dependence on imports of } \\
\text { food in Botswana. To enhance economic growth, in both the short run and long run, the government of } \\
\text { Botswana and all relevant stakeholders should invest in and promote livestock production. In the long } \\
\text { term, policies that foster crop production are essential for economic growth. }\end{array}$ \\
\hline
\end{tabular}

mmatandare1@gmail.com (iD) https://orcid.org/0000-0002-8371-8872

$\begin{array}{ll}\text { setlharel@ub.ac.bw } & \text { (iD) https://orcid.org/0000-0003-4278-5603 }\end{array}$

b pmakepe@biust.ac.bw

d@thalefj@ub.ac.bw
(D) https://orcid.org/0000-0001-9466-0250

iD https://orcid.org/0000-0003-1603-606X

(c) (1) ) T) This work is licensed under Creative Commons Attribution 4.0 International License

\section{Introduction}

Economic growth is proposed to be one of the primary and fundamental objectives of developing countries (Hussain and Khan, 2011). For most of these developing countries, the agriculture sector is generally observed as an engine for growth (Byerlee et al., 2005; Headey et al., 2005; Awokuse, 2008). Theoretically and empirically there is consensus that a change in agriculture could change an economy's overall output (Johnston and Mellor, 1961; Jorgenson, 1961; Chennery and Strout, 1966; Dawson, 2005; Tiffin and Irz, 2006).

However, the balance between agriculture and industry in the growth of developing countries is still an issue of debate. Ghatak (2003); Ofori (2006) and TandrayenRagoobur (2010) noted that many developing countries notably Southern African countries, in their need for rapid economic growth, have sought to promote industrialization as quickly as possible. Despite various policies, trade agreements and growth enhancing policies, the growth prospects in African countries remained minimal. Southern
African countries have been pointed as lagging behind their Northern and Western African counterparts in terms of growth and development (World Bank, 2008).

Botswana's economic growth after its independence in 1966 was regarded as nothing short of a miracle. However, challenges which include food import dependence, youth unemployment, land shortages and slow agro-processing sector growth have been affecting Botswana. Lack of a dynamic agriculture sector and pro-service and mining industries policies in the twenty first century has limited Botswana's potential for growth and development (Badiane and Makombe, 2014). Although the contribution of the agriculture sector to GDP is minimal, it is vital to livelihood for many Batswana who operate farms for subsistence. Livestock production, especially cattle, contributes an estimated $80 \%$ to the agricultural GDP (MoA, 2017). Botswana's agriculture national significance stems from the fact that close to 50 per cent of the total population live in rural areas, and a significant proportion 
of those rural dwellers still depend on agriculture for a substantial portion of their incomes and livelihoods (WDI, 2017). The agriculture sector accounts for 25 per cent of total employment, both formal as well as informal, (FAO, 2016).

The performance of the Botswana economy in recent years is shown on Table 1.

Botswana has maintained impressive economic growth and low stable inflation rate between 2010 and 2015 . Interest rates have continually decreased which has been good for attracting investments. Most of the population reside in urban areas as compared to rural areas because people seek better amenities and job opportunities and better living standards in towns and cities. Imports have been continually higher than exports over the study period (FAO, 2016). Agriculture productivity in Botswana has been stagnant for the past three decades due to various socio-economic, environmental and technological factors (Leinberg, 2013; and MoA, 2017).

Agriculture food deficit draws down reserves for the country (Mazonde, 1993; and Jefferis and Nemaorani, 2014). There is need to improve production skills so as to increase agriculture output (Mbulawa, 2017). Of note is that livestock rearing is Botswana's key agricultural output and export (Makoni, 2015). The crop sub-sector is dominated by the growth of cereals, but is limited by unreliable rainfall, constrained productivity in the sector, and the fact that desert and poor soils cover $70 \%$ of the country (FAO, 2016).

Agriculture, value added, as a proportion to Gross Domestic Product (GDP) decreased significantly between 1980 and 2016 (FAO, 2016). The same trend was also expected for employment in agriculture (\% of total employment). However, Botswana actually recorded increases in employment in agriculture. Botswana posted an increase from $26.4 \%$ to $29.9 \%$ between 2000 and 2016 (FAO, 2016). This further reiterates the importance of agriculture in Botswana and the need to promote agriculture growth as it has a large bearing on the livelihoods of many households and as a key driver of economic growth.

Agriculture's declining share of national output during the economic transformation is particularly responsible for the widespread misunderstanding in many countries that agriculture is unimportant and does not require public investment and a favorable policy environment (Timmer, 1990). But Timmer shows that the combination of agricultural growth and relative decline in economic growth is not a paradox of a normal and desirable process and that continuing public and private investments in agriculture are essential to completing the transformation process. This is not the case for Botswana whose support for the agricultural sector has continued to decline over the years.

The objective of this paper is to analyze the impact of crop production and livestock production on economic growth in Botswana. Hence this study seeks to answer the following research questions:

- What is the impact of crop production on economic growth in Botswana?

- What is the impact of livestock production on economic growth in Botswana?

The motivation of the paper is based on the notion that theory presents a strong case for the positive influence of aggregate agriculture on economic growth, however empirical evidence on the effect of particular agriculture sub sectors is limited. The norm has been generalizing agriculture in totality instead of focusing on its various subsectors. On this front, this study extends the agriculture contribution by reviewing two main sub-components indicators of agriculture in Botswana namely crop production and livestock production. Such inferences especially on crop production will enable the study to provide specific recommendations which can aid developing countries in achieving not only increase in production but also food security, poverty reduction and economic growth.

Some scholars believe that the development of the agriculture sector is a precondition of growth (Ehui and Tsigas, 2009; Ocholi, 2011; and Herath, Bashir, Gebremedhin, 2013), others are of the belief that industrial sector development is a pre-condition to growth in the economy (Szirmai, 2009; and Loto, 2012). Empirical evidence on agriculture sector effect on economic growth in Botswana is also limited.

Advocates of agriculture-led growth contended that development of the agriculture sector was a pre-requisite for industrialization through rural income increase, raw materials provision and resource release to support the industry (Chennery and Strout, 1966). Neglecting the agriculture sector in favor of the industrial sector would thus lead to slow economic growth (Riezman, 1996). Early advocates like physiocrats argued that development of an economy depended on agriculture sector growth. Physiocrats emphasized that agriculture was critical in economic development and the economy was regulated by productivity in agriculture (Matthew and Mordecai, 2016).

Table 1. Botswana - Performance of the economy in recent years

\begin{tabular}{l|cccccc}
\hline & 2010 & 2011 & 2012 & 2013 & 2014 & 2015 \\
\hline GDP per capita (US\$) & $6,346.1$ & $6,610.3$ & $6,779.3$ & $7,409.4$ & $7,574.2$ & $7,308.6$ \\
Imports (US\$) ('000 000) & 6,554 & 7,815 & 10,322 & 11,431 & 11,371 & 11,413 \\
Exports (US\$) ('000 000) & 5,579 & 7,116 & 8,386 & 11,430 & 11,321 & 10,212 \\
Lending interest rate (\%) & 11.4 & 11 & 11 & 10.1 & 9 & 7.95 \\
Inflation (\%) & 6.9 & 8.4 & 7.5 & 5.8 & 4.4 & 3 \\
Rural population & 881,806 & 893,009 & 904,694 & 916,578 & 928,431 & 940,146 \\
Urban population & $1,133,060$ & $1,158,330$ & $1,184,621$ & $1,211,929$ & $1,240,142$ & $1,269,051$ \\
Exchange rate (LCU per US\$) & 6.7 & 6.8 & 6.8 & 8.3 & 8.9 & 10.1 \\
\hline
\end{tabular}


Fisher- Clark theory of structural change by Fisher (1935) and Clark (1940) stated that every economy pass through three stages - agricultural, industrial and then services. Hirschman (1958) also strongly influenced development philosophy in the fifties. Hirschman proposed the concept of linkages as a tool for examining how investment in one type of activity induced successive investment in the other income-generating activities. This influenced the development thinking which supported import substitution industrialization as well as agriculture being a supportive role to the industrial sector. The notion of agriculture led growth approach was thus further influenced by Johnston and Mellor (1961), as well as Schultz (1961) among others. Emphasis was put on the role of smallholder farming in stimulating growth and development. (Prebisch and Singer, 1949; Rostow, 1960; Jorgenson, 1961; Fei and Ranis, 1961).

Other advocates of the process of development being characterized by a movement of labour from low-productivity agriculture to high-productivity manufacturing also cropped up (Lewis, 1954; Johnston and Mellor, 1961; Kuznets, 1968). Schultz (1964) was among the earlier economists who emphasized that productivity led agricultural transformation could make a much more important contribution to the economy than just providing surplus labour and savings to support industrialization. These sector linkages were further emphasized by Singer (1979) who stated that, because of production and consumption linkages, a country's development strategy should not be export driven but rather agriculture driven. Therefore, increased agricultural productivity would be the initiator of industrialization (Dethier and Effenberger, 2011).

Jatuporn et al. (2011) investigated the long run relationship between agriculture and economic growth for Thailand between 1961 and 2009. The study findings revealed a long run relationship between agriculture and economic growth and concluded that policy makers should regard agriculture as playing an important role in enhancing economic growth. Faridi (2012) employed the Johansen's cointegration technique for the period 1972 to 2008 to examine the contribution of agricultural exports to economic growth. The study findings showed that the agricultural exports had a negative and significant effect on economic growth. Thus, the study suggested the promotion of non-agricultural exports.

Vogal (1994) as cited in (Byerlee et al., 2005) analysed the strength of agriculture sector as a factor of economic growth for 27 countries. He discovered that agriculture through its backward and forward linkages leads to positive integration of the sector with the broader economy. Using ordinal least square regression analysis method Onunze (2012) found out that agriculture influenced economic growth positively.

In North Carolina, for the period 2000 to 2010, Herath, Bashir and Gebremedhin (2013) examined the relationship between agricultural sector and economic growth. Increasing income was found to increase agricultural activities and vice versa. The study concluded that countries with high income were more capable of improving agriculture production as high income would prompt more investment in the agricultural sector, thereby increasing production. Farooqi and Qureshi (2015) investigated agriculture sector share role in Pakistan's
GDP. Data for 1975 to 2012 period was used. For estimation of the parameters, the ordinary least squares methodology was employed. Several variables which include industry, agriculture and trade were reviewed. The study results reflected significant and positive relationship between agriculture and GDP.

A causal relationship between agricultural value addition and economic growth in Namibia employing annual data for the period 1980 to 2015 was investigated by Odero (2017). Using the Vector Autoregressive approach, the results revealed a unidirectional causal relationship running from agricultural value added to economic growth. More studies also pointed to the important role of agriculture to economic growth (Arndt et al., 2000; Thirtle et al., 2001; Hanmer and Nashchold, 2000; Irz et al, 2001; Kanwar, 2000; Matsuyama, 1992; Ravallion and Datt, 1999; Stern, 1996; Timmer, 2003; Wichmann, 1997; Dorosh et.al, 2003; Byerlee, De Janvry and Sadoulet, 2009; Awokuse and Xie, 2015).

Initially based on agriculture and heavily dependent on foreign aid, the rapid economic growth and general development in Botswana have been driven by the mining sector, (Maipose and Matsheka, 2010). With a decrease in international mineral prices and depletion of the nonrenewable mining resources, the need to diversify the economy so as to ensure sustainable economic growth has been of great concern. Accelerating productivity in agriculture is seen as one of the alternatives to support the diversification initiatives by the government and drive growth in Botswana (Mbulawa, 2017). Mbulawa (2017) investigated the relationship between agriculture productivity and economic growth in Botswana. Results of the study showed that economic growth can be improved in the short term by improvements in agricultural productivity. Agricultural productivity can be enhanced by providing adequate infrastructure, additional farming machinery per hectare of arable land and having a targeted approach in the provision of funding towards agricultural oriented initiatives.

A study by the GoB (2008) on diversification of the Botswana economy possibilities concluded that agriculture provides an avenue for diversification with potential contribution to economic growth, employment and poverty reduction. Hence, meaningful diversification of the economy can be achieved by supporting agro-based projects. Agriculture has potential to create a new platform for exports and to bring meaningful industrial activity among the rural populace. Matambo (2014) also reiterated that agriculture in Botswana is labour intensive absorbing much of the unskilled labour force. It has potential to be part of the global value chains and gain access to prime international markets.

In earlier debates on economic development, the agricultural sector's role was somewhat controversial. While dualistic models highlighted the importance of agriculture, the mainstream literature placed a greater emphasis on the creation of a modern industrial sector. Soon agriculture disappeared from the mainstream development literature to re-emerge recently with a variety of multiple-sector growth models emphasizing the key role of agriculture in economic growth. This paper seeks to reexamine the impact of agriculture via disaggregated sectors (crop production and livestock production) on economic growth using modern econometric techniques. 


\section{Materials and Methods}

Autoregressive Distributed Lag (ARDL) procedure will be adopted to estimate long run and short run dynamic interactions. ARDL approach includes lags of both endogenous variable and exogenous variables as regressors
(Greene, 2008). Pesaran and Shin (1999) and Pesaran et al. (2001) developed the ARDL method. The ARDL representation of the general empirical model to be estimated in this study is specified in equation (1):

$$
\begin{aligned}
\Delta \text { OUTP }_{t}=\psi_{0}+ & \sum_{k=1}^{p} \psi_{1 k} \Delta \text { OUTP }_{t-k}+\sum_{k=0}^{q_{1}} \psi_{2 k} \Delta A G R I_{t-k}+\sum_{k=0}^{q_{2}} \psi_{3 k} \Delta C A P L_{t-k} \\
& +\sum_{k=0}^{q_{3}} \psi_{4 k} \Delta L A B R_{t-k}+\sum_{k=0}^{q_{5}} \psi_{5 k} \Delta E X P O_{t-k}+\sum_{k=0} \psi_{6 k} \Delta I N F L_{i, t-k}+\beta_{1} O U T P_{t-1} \\
& +\beta_{2} A G R I_{t-1}+\beta_{3} \text { CAPL }_{t-1}+\beta_{4} L A B R_{t-1}+\beta_{5} \text { EXPO }_{t-1}+\beta_{6} I N F L_{t-1}+\eta_{1 t}
\end{aligned}
$$

Where: OUTP - Economic growth; AGRI - Agriculture production; $C A P L$ - Capital; $L A B R$ - Labour; EXPO Exports; INFL - Inflation; $\psi_{0}$-constant; $\beta_{1}, \ldots \ldots, \beta_{6}$, and $\psi_{1 k}, \ldots \ldots, \psi_{6 k^{-}}$are the respective coefficients; $\Delta-$ the first-difference operator; $p, q 1, q 2, q 3, q 4$ and $q 5$ are optimal lag length; $t$ is the time period and; $\eta_{1 t}$ - the error term that are assumed to be normally distributed and white noise. Considering main subcomponents of agriculture in Botswana namely crop production and livestock production we have:

$$
\begin{aligned}
\Delta \text { OUTP }_{t}=\psi_{0}+ & \sum_{k=1}^{p} \psi_{1 k} \Delta \text { OUTP }_{t-k}+\sum_{k=0}^{q_{1}} \psi_{2 k} \Delta C R O P+\sum_{k=0}^{q_{1}} \psi_{3 k} \Delta A N I M_{t-k} \\
& +\sum_{k=0}^{q_{2}} \psi_{4 k} \Delta C A P L_{t-k}+\sum_{k=0}^{q_{3}} \psi_{5 k} \Delta L A B R_{t-k}+\sum_{k=0}^{q_{4}} \psi_{6 k} \Delta E X P O_{t-k} \\
& +\sum_{k=0}^{q_{5}} \psi_{7 k} \Delta I N F L_{i, t-k}+\beta_{1} O U T P_{t-1}+\beta_{2} C R O P_{t-1}+\beta_{3} A N I M_{t-1}+\beta_{4} C A P L_{t-1} \\
& +\beta_{5} L A B R_{t-1}+\beta_{6} E X P O_{t-1}+\beta_{7} I N F L_{t-1}+\eta_{2 t}
\end{aligned}
$$

Where: CROP - Crop production and ANIM livestock production. The optimal lag structure will be selected using SBC. Initial step in the ARDL method is used for estimation of equations (2) by Ordinary Least Squares (OLS). F-test will be applied to test for existence of long-run relationship between variables by restricting coefficients of lagged levels of variables to zero. The above model is estimated for Botswana. The test imposes the following null hypotheses of no cointegration relationship:

$$
\mathrm{H} 0: \beta_{1}=\beta_{2}=\beta_{3}=\beta_{4}=\beta_{5}=\beta_{6}=\beta_{7}=0
$$

Tested against the alternative hypothesis of the existence of a cointegration relationship:

$$
\mathrm{H} 1: \beta_{1} \neq \beta_{2} \neq \beta_{3} \neq \beta_{4} \neq \beta_{5} \neq \beta_{6} \neq \beta_{7} \neq 0
$$

For a given level of significance two critical value sets can be determined (Pesaran et al., 2001). First level is estimated assuming that all variables in ARDL model are zero order integrated, while second level is estimated assuming all variables are order one integrated. Null hypothesis of no cointegration will be rejected if test statistic value is above upper critical bounds value, and will not be rejected when the F-statistic is below the lower bounds value. Otherwise, the cointegration approach would be inconclusive if the result of the F-statistic lies inbetween the critical value of lower bounds and critical value of the upper bounds.

ARDL approach is preferred for this study as it can be used for small sample size for more robust and consistent results. ARDL approach is not restricted by the order of integration amongst the variables as it can be applied whether the variables under the study are not integrated of the same order. Finally, different number of lags is plausible for different variables under the ARDL approach (Nayaran, 2005).

\section{Error Correction Model}

The error correction model, associated with the longrun equation above, is represented by:

$$
\begin{aligned}
& \Delta \operatorname{OUTP}_{t}=\psi_{0}+\sum_{k=1}^{p} \psi_{1 k} \Delta O U T P_{t-k}+\sum_{k=0}^{q_{1}} \psi_{2 k} \Delta C R O P_{t-k}+\sum_{k=0}^{q_{1}} \psi_{3 k} \Delta \text { ANIM }_{t-k}+\sum_{k=0}^{q_{2}} \psi_{4 k} \Delta C A P L
\end{aligned}
$$

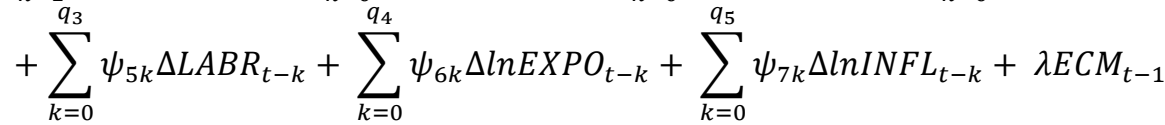

$$
\begin{aligned}
& +\mu_{t}
\end{aligned}
$$


Where all the variables are as already defined, with the exception of $E C M_{t-1}$, which is the error correction term lagged one period and its coefficient $(\lambda)$. The coefficient of the error-correction term lagged one period $\left(E C M_{t-1}\right)$, which is also the speed of adjustment parameter, is expected to be negative and statistically significant to further confirm the existence of a cointegration relationship.

\section{Results and Discussion}

\section{Unit Root Tests}

Time series unit root tests was carried out using the Perron (1997) Unit Root test (PPURoot) as shown on Table 2.

For Botswana, Table 2 above confirms that all the variables under consideration are at most integrated of order 1. The ARDL approach is only applicable for the analysis of variables that are integrated of an order not more than one. Table 2 confirms that the ARDL bounds testing procedure will not breakdown because all variables are integrated of maximum order 1.

\section{Cointegration Test - ARDL}

The existence of cointegration between variables was tested using the ARDL bounds testing approach to cointegration. Schwartz Bayesian Criterion (SBC) was used to select the appropriate lag length.

SBC was used for selection of the lag length. Table 3 above presents the empirical results of the ARDL bounds tests for cointegration.
Bounds F-test for cointegration indicates that the computed F-statistic is greater than the upper critical bound at the $1 \%$ level of significance. This implies that there is cointegration between the series and it confirms that output, crop production, livestock production, capital, labour, exports and inflation are cointegrated over the period of study. Thus, given the confirmation of cointegration, the optimal lag length selected based on SIC is ARDL $(1,0,0,1,1,2,1)$. The results from the bounds cointegration test indicate that both long run and short-run relationships exist for the variables under study.

Table 4 and Table 5 shows the estimated long run and short run results respectively. Table 4 presents the results of the long run coefficient estimates of the ARDL model. Consistent with economic theory, crop production and livestock production have a positive and significant effect on economic growth in the long run. This can be stated that, in the long-run, an increase in crop production and livestock production would result in an increase in economic growth respectively. Thus crop and livestock production drives the agriculture sector which presents an opportunity to drive economic growth expansion. These results are similar to the findings of Oje-Okoro, (2011); Izuchukwu, (2011); Behnke and Muthami, (2011); and Gelan, Ermias, Stefano and Kaugia, (2012).

Other results from Table 4 show that the coefficient of capital is positive and significant in the long run. This confirms a positive impact of capital on economic growth in Botswana.

Table 2. Unit Root Tests for Botswana - Perron (1997) Unit Root Test (PPURoot)

\begin{tabular}{l|ccccc}
\hline \multirow{2}{*}{ Variable } & \multirow{2}{*}{ OI } & \multicolumn{2}{c}{ Stationarity in levels } & \multicolumn{2}{c}{ Stationarity in first differences } \\
\cline { 3 - 6 } & & Without trend & With trend & Without trend & With trend \\
\hline OUTP & $\mathrm{I}(1)$ & -4.46632 & -4.27576 & $-9.61838^{* * *}$ & $-8.23235^{* * *}$ \\
CAPL & $\mathrm{I}(1)$ & -4.57928 & -4.34301 & $-6.23771^{* * *}$ & $-6.47043^{* * *}$ \\
LABR & $\mathrm{I}(1)$ & -4.78102 & -3.08174 & $-6.52858^{* * *}$ & $-9.71355^{* * *}$ \\
EXPO & $\mathrm{I}(0)$ & $-5.81673 * *$ & $-6.52163 * * *$ & - & - \\
INFL & $\mathrm{I}(0)$ & $-5.57397 * *$ & $-5.74695 * *$ & - & - \\
CROP & $\mathrm{I}(1)$ & -3.82944 & -3.12687 & $-6.6723 * * *$ & $-6.12042^{* * *}$ \\
ANIM & $\mathrm{I}(0)$ & $-6.20203 * * *$ & $-7.27585 * * *$ & - & - \\
\hline
\end{tabular}

OI: Order of integration, Note: *, ** and *** denote stationarity at the $10 \%, 5 \%$ and $1 \%$ significance levels respectively

Table 3. Bounds F-Test for Cointegration

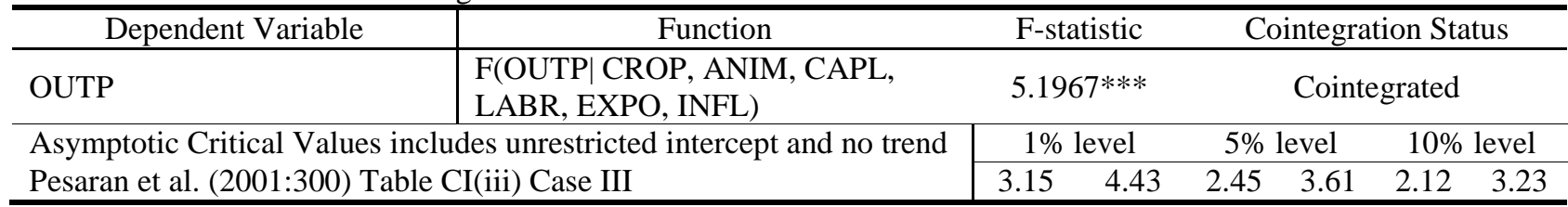

Note: $* * *$ and $* * *$ denotes significance at the $10 \%, 5 \%$ and $1 \%$ significance levels respectively

Table 4. Estimated Long-run Coefficients

\begin{tabular}{l|cccc}
\hline \multicolumn{2}{l}{ Panel A: Estimated Long-Run Coefficients - Dependent Variable is OUTP } & & \\
\hline \multicolumn{1}{c}{ Regressor } & Coefficient & Standard Error & T-Ratio & Prob-Values \\
CROP & 0.2723 & 0.10516 & 2.590 & $0.022^{* *}$ \\
ANIM & 0.01267 & 0.00698 & 1.81307 & $0.071^{*}$ \\
CAPL & 0.61143 & 0.09723 & 6.28915 & $0.000^{* * *}$ \\
LABR & -0.2037 & 0.2516 & -0.8097 & 0.433 \\
EXPO & 0.24451 & 0.1440 & 1.6975 & 0.113 \\
INFL & -0.29212 & 0.12808 & -2.28041 & $0.023 * *$ \\
C & -3.3971 & 11.9341 & -0.2847 & 0.780 \\
\hline
\end{tabular}


Table 5. Estimated Short-Run Coefficients

\begin{tabular}{l|cccc}
\hline \multicolumn{1}{c}{ Panel B: Estimated Short-Run Coefficients - Dependent Variable is dOUTP } & & \\
\hline \multicolumn{1}{c}{ Regressor } & Coefficient & Standard Error & T-Ratio & Prob-Values \\
\hline dCROP & 0.0273 & 0.0906 & 0.3016 & 0.767 \\
dANIM & 0.1859 & 0.0779 & 2.3874 & $0.029^{* * *}$ \\
dCAPL & 0.2317 & 0.0741 & 3.1274 & $0.006^{* * *}$ \\
dLABR & -0.2047 & 0.2623 & -0.7804 & 0.446 \\
dEXPO & 0.6232 & 0.1079 & 5.7746 & $0.000^{* * *}$ \\
dINFL & -0.3098 & 0.1483 & -2.0884 & $0.052^{*}$ \\
ECM (-1) & -0.7110 & 0.1819 & -5.4643 & $0.000^{* * *}$ \\
\hline
\end{tabular}

R-Squared 0.9273 R-Bar-Squared 0.8602

S.E. of Regression 2.2665 F-Stat.F(8,17) 20.7339 [0.000]

Residual Sum of Squares 66.7811 DW-statistic 2.0803

Akaike Info. Criterion -62.1556 Schwarz Bayesian Criterion -70.3332

Note: $* * *$ and $* * *$ denotes significance at the $10 \%, 5 \%$ and $1 \%$ significance levels respectively

Table 6. ARDL-ECM Diagnostics Tests for Botswana

\begin{tabular}{l|c}
\multicolumn{1}{c|}{ LM Test Statistics } & Results \\
\hline Serial Correlation & $3.0898[0.079]$ \\
Functional Form & $10.3128[0.001]$ \\
Normality & $0.6066[0.738]$ \\
Heteroscedasticity & $0.1392[0.709]$ \\
\hline
\end{tabular}

These results are similar to findings by Beddies, (1999); Aubyn and Afonso (2008); and Assaf (2014) who found a positive and significant relationship between capital and economic growth in developing countries. Furthermore, in line with economic theory, inflation has a negative and significant effect on economic growth in the long run. This implies that price instability has a negative impact on economic growth in Botswana. These results are similar to Manoel (2010), Ziaur (2013), Ferdinand and Isidore (2014); and Chude and Chude (2015).

Table 5 indicates that livestock production has a significant and positive impact on economic growth while crop production has a positive but insignificant impact on economic growth in the short run. Crop production is severely affected by land type, ownership and fertility as well as erratic rains in Botswana. Hence majority of farmers in Botswana are into livestock production as the semi-arid climatic conditions are more suitable for livestock production (Badiane and Makombe, 2014).

From table 5, it can be stated that, in the short-run, an increase in capital by $1 \%$ would result in $0.23 \%$ increase in economic growth. This results conforms to the study expectations and economic theory. This implies a positive impact of capital on economic growth in Botswana. This result is similar to the findings of Sallam, (2014); and Makuyana and Odhiambo, (2018). More so, exports exhibited a positive sign and it was significant at $1 \%$ in the short-run. Empirical results by Njikam (2003); and Nyasulu (2013) suggested an evidence of a positive association between the exports and the growth rate of developing economies. The entire coefficients are significant in the short run except for labour and crop production. The estimated short-run coefficients for the subcomponents of agriculture reveals and implies that livestock production contributes significantly to economic growth in the short run as compared to crop production in Botswana.
Given the findings presented in table 5 above, the error correction term [ECM (-1)] is both significant and negative. This endorses the economic theory expected results. The error correction term [ECM (-1)] of -0.7110 is interpreted as the speed of adjustment to long run equilibrium. Therefore, this indicates that approximately $71 \%$ of all the deviations in the past will be corrected (adjusted to the equilibrium) during the present period. The high value of the error term indicates that the economic agents remove a large percentage of disequilibrium in each period. $\mathrm{R}^{2}$ of 0.9273 implies that approximately $92.73 \%$ of the changes in the explained variable are brought about by the changes in independent variables.

\section{Diagnostic Tests}

Diagnostic tests were employed to ascertain the goodness of fit of the ARDL models. LM test statistics were observed and the key diagnostic tests focused mainly on assessing serial correlation, the functional form, normality and heteroscedasticity incidence. Table 5 below summarizes the results of the diagnostic tests for Botswana:

Whereas the diagnostic test results in Table 6 indicate that the model passes all the diagnostic tests, it fails on the functional form. Therefore, to check for model stability, the study plotted the cumulative sum of recursive residuals (CUSUM) and cumulative sum of squares of recursive residuals (CUSUMQ) and the results are displayed in Figure 1 and Figure 2. The null hypothesis may be accepted if the plots of both statistics lie inside the critical boundaries at $5 \%$ level of significance.

As shown in Figures 1 and 2, the model pass the stability test as revealed by CUSUM and CUSUMQ plots which are within the boundaries at 5\% significance level, signifying that the estimated results are consistently reliable. 


\section{Conclusion and Recommendations}

In this study, we empirically investigated the impact of crop production and livestock production on Botswana's economic growth. The results revealed that during the chosen period of study $(1990-2017)$ crop production and livestock production had positive and significant effect on economic growth in the long run. Livestock production contributes positively and significantly to economic growth in the immediate period as compared to crop production which was positive but insignificant in the short run. As hypothesised, the error correction term $\operatorname{ECM}(-1)$ is found to be negative and statistically significant at $1 \%$. CUSUM and the CUSUMSQ stability test confirmed that the long-run coefficients and all short-run coefficients in the error correction model were stable.

In light of the above findings, this study confirms the role and importance of agriculture as a backbone in feeding developing nations towards achieving food security and increasing economic growth. Agriculture in Botswana resounds with Sustainable Development Goal (SDG) number 2 which seeks to end hunger (Van Niekerk, 2020). This can only be achieved by promoting sustainable crop production and livestock production not only in the short run but also in the long run. The following recommendation are proposed to encourage and improve agriculture output and economic growth in Botswana:

- All relevant ministries and organizations should be extremely sensitive and definitely take steps in their action plans to promote the agriculture sector.

- Government should provide adequate infrastructure and policy framework that will be conducive for increasing agriculture output.

- Government's effort towards an integrated agricultural sectorial policies in Botswana is essential towards achieving sustainable agriculture and economic growth.

- Finally, Government of Botswana's effort towards investing and promoting scientific research in technological advancement in crop yield and livestock yield will be essential to achieving a sustainable agriculture and economic growth.

\section{Limitations of the Study and Areas for Further Research}

As is the case with many scientific studies, this research has a few limitations, despite the effort made to ensure that the study is analytically defensible. Foremost, the short time series data used in the empirical analysis is one probable limitation. Though the use of the ARDL approach might have lessened the problem of insufficient data, future research work should be carried out when there is sufficient data available to ascertain whether their result will differ fundamentally from the results of this study.

The study also made use of only two sub sectors of agriculture namely crop production and livestock production. Future studies may wish to explore the use of other subsectors to determine whether their findings will differ fundamentally from the results of this study.
An inference into the effects of climate change on subsectors of agriculture is also suggested.

Despite the said limitations, this research paper provides a comprehensive insight into the agriculture and economic growth nexus in Botswana.

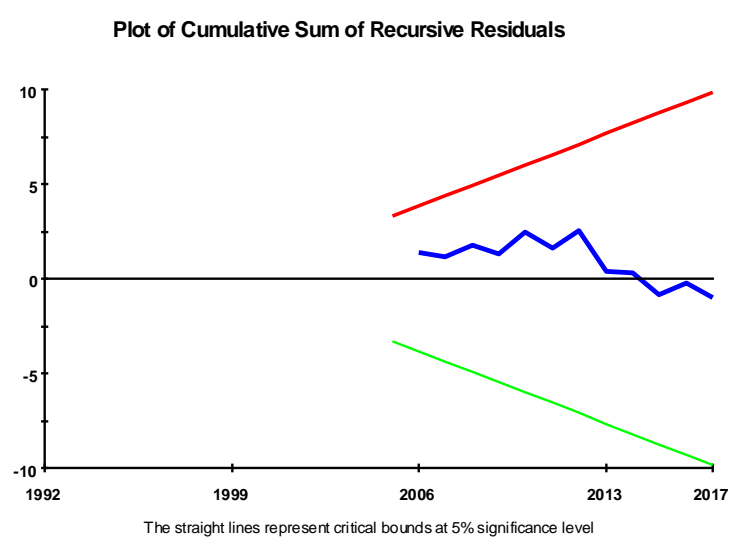

Figure 1. Plot of CUSUM

Plot of Cumulative Sum of Squares of Recursive Residuals

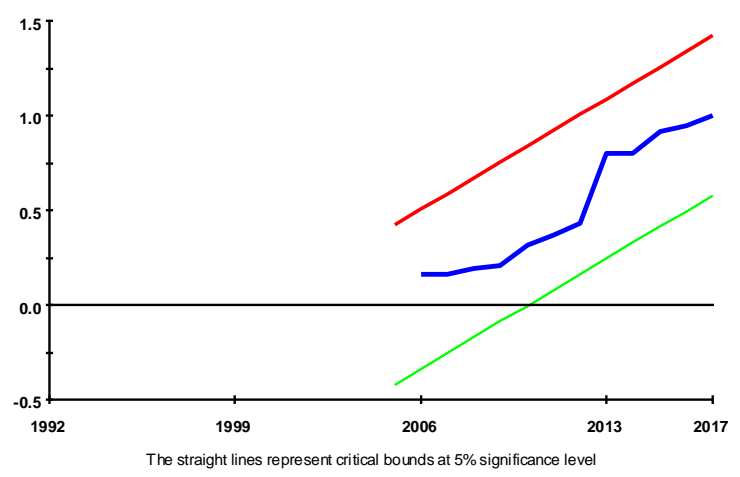

Figure 2. Plot of CUSUMQ

\section{Acknowledgement}

This research article was produced from Mufaro Andrew Matandare's PhD thesis (Economics Department, University of Botswana).

\section{References}

Arndt C, Jensen HT, Robinson S, Tarp F. 2000. Marketing Margins and Agricultural Technology in Mozambique. Journal of Development Studies, 37(1): 121-137.

Assaf AA. 2014. The Effect of Macroeconomic Variables on Jordan's Economic Growth. European Journal of Social Sciences, 42(1): 101-111.

Aubyn MS, Afonso A. 2008. Macroeconomic Rates of Return of Public and Private Investment: Crowding-in and Crowdingout Effects. Department of Economics, Technical University of Lisbon Working Paper No. WP/06/2008/DE/UECE.

Awokuse TO, Xie R. 2015. Does Agriculture Really Matter for Economic Growth in Developing Countries? Canadian Journal of Agricultural economics, Vol 63: 77-99. 
Awokuse TO. 2009. Does Agriculture Really Matter for Economic Growth in Developing Countries. American Agriculture Economics Association, Agricultural Economics, 33(2): 145-152.

Badiane O, Makombe T. 2014. The theory and practice of agriculture, growth and development in Africa. WIDER Working Paper Series 061, UN University.

Bahmani-Oskooee M, Brooks TJ. 2003. A New Criteria for Selecting the Optimum Lags in Johansen's Cointegration Ttechnique. Applied Economics, 35(8): 875-880.

Beddies CH. 1999. Investment, Capital Accumulation and Growth: Some Evidence from the Gambia 1964-98. IMF Working Paper No. WP/99/117.

Behnke R, Muthami R. 2011. The Contribution of Livestock to the Kenyan Economy. IGAD LPI Working Paper No. 03-11.

Brownson S, Vincent IM., Emmanuel G, Etim D. 2012. Agricultural Productivity and Macroeconomic Variable Fluctuation in Nigeria. International Journal of Economics and Finance, 4(8): 114-133.

Byerlee D, De Janvry A, Sadoulet E. 2009. Agriculture for Development: Towards a New Paradigm. Annual Review of Resource Economics, 1: 5-31.

Byerlee D, Diao X, Jackson C. 2005. Agriculture, Rural Development, and Pro-poor Growth: Country Experiences in the Post-reform Era. Synthesis Paper for the Operationalizing Pro-poor Growth in the 1990s Project. Washington DC: The World Bank.

Chennery HB, Strout AM. 1966. Foreign Assistance and Economic Development. The American Economic Review, 56(4): 679-733.

Chude DI, Chude NP. 2015. Impact of Inflation on Economic Growth in Nigeria.

Dawson P.J. 2005. Agricultural Exports and Economic Growth in Less Developed Countries. The Journal of International Association of Agricultural Economics, 33(2): 145-152.

Dethie J, Effenberger A. 2011. Agriculture and Development: A Brief Review of the Literature. Economic Systems. Vol 36: 175-205.

Ehui SK, Tsigas ME. 2009. The Role of Agriculture in Nigeria's Economic Growth: A General Equilibrium Analysis. International Association of Agricultural Economists, 2009 Conference, Beijing, China.

FAO. 2016. FAO Metadata - Countries. Food and Agriculture Organization, Rome, Italy.

FAO. 2016. FAO Statistics. Food and Agriculture Organization, Rome, Italy.

Faridi M. 2012. Contribution of Agricultural Exports to Economic Growth in Pakistan. Pak. J. Commer. Soc. Scl,6 (1): 133- 146.

Fei JCH, Ranis G. 1961. A theory of Economic development. The American Economic Review, 51(4): 653-665.

Ferdinand A, Isidore AA. 2014. Short-run and Long-run Inflation and Economic Growth Nexus in Ghana. Ghana Journal of Development Studies, 11(2).

Gelan A, Ermias E, Stefano C, Kaugia J. 2012. Integrating Livestock in the CAADP Framework: Policy Analysis Using a Dynamic Computable General Equilibrium Model for Ethiopia. Ethiopia Strategy Support Program II (ESSP II). Working Paper No 34.

Ghatak S. 2003. Introduction to Development Economics. $4^{\text {th }}$ Edition. London, Routledge.

GoB. 2008. A strategy for economic diversification and sustainable growth. Gaborone: Government Implementation and Coordination Office, Botswana.

Greene WH. 2003. Econometric Analysis. 5 $5^{\text {th }}$ Edition. NJ, Prentice hall.

Headley OD, Rao DSP, Allaudin M. 2005. Explaining Agricultural Productivity Levels and Growth: An International Perspective. IFPRI Discussion Paper 801. International Food Policy Research Institute.
Herath J, Bashir S, Gebremedhin T. 2013. An Empirical Analysis of Agriculture in Economic Growth of North Carolina. Southern Agricultural Economics Association.

Hirschman AO. 1958. The Strategy of Economic Development. Yale University Press, New Haven.

Hussain A, Khan AQ. 2008. Relationship between Agriculture and GDP Growth Rates in Pakistan: An Econometric Analysis (1961-2007). Academic Research International, 1 1(2): 322-326.

Hwa EC. 1983. The Contribution of Agriculture to Economic Growth: Some Empirical Evidence. World Development, 16(11): 1329-1339.

Irz X, Lin L, Thirtle C, Wiggins S. 2001. Agricultural Productivity Growth and Poverty Alleviation. Development Policy Review, 19: 449-466.

Izuchukwu O. 2011. Analysis of the Contribution of Agricultural Sector on the Nigerian Economic Development. World Review of Business Research, 1(1): 191-200.

Jatuporn C, Chien L, Sukprasert P, Thaipakdee S. 2011. Does a Long Run Relationship Exist between Agriculture and Economic Growth in Thailand? International Journal of Economic and Finance, 3(3).

Jefferi K, Nemaorani T. 2014. Botswana country overview. Gaborone, Botswana.

Jogenson DW. 1961. The Development of a Dual Economy. Economic Journal, 71(282): 309-334.

Johnston BF, Mellor JW. 1961. The Role of Agriculture in Economic Development. The American Economic Review, 51(4): 566-593.

Johnston BF. 1961. Growth in Agriculture and Manufacturing. Asian Economic Review, 5(2): 221-235.

Kuznets, S. 1968. Economic Growth and Income Equality. The American Economic Review. XLV(1).

Lewis WA. 1954. Economic Development with Unlimited Supplies of Labour. The Manchester School, 22(1): 139-191.

Liebenberg F. 2013. South African Productivity and Research Performance in the 20th Century. PhD dissertation, University of Pretoria.

Loto MA. 2012. Global Economic Downturn and the Manufacturing Sector Performance in the Nigerian Economy (A Quarterly Empirical Analysis). Journal of Emerging Trends in Economics and Management Sciences (JETEMS), 3 (1): 38-45.

Lutkepohl H. 2005. New Introduction to Multiple Time Series Analysis. Springer-Verlag, Berlin, Germany.

Maipose GS, Matsheka TC. 2010. Explaining African Growth Performance: The Botswana Case Study, University of Botswana. Botswana.

Makuyana G, Odhiambo NM. 2018. Public and Private Investment and Economic Growth in Zambia: A Dynamic Approach. International Economics. 71(4): 503-526.

Manoel B. 2010. Inflation and Economic Growth in Latin America: Some Panel Time Series Evidence. University of Pretoria Department of Economics Working Paper Series.

Matambo OK. 2014. Budget speech. Ministry of finance and development planning. Government of Botswana, Botswana.

Matsuyama K. 1992. Agricultural Productivity, Comparative Advantage, and Economic Growth. Journal of Economic Theory, 58: 317-334.

Matthew A, Mordecai D. 2016. The Impact of Agricultural Output on Economic Development in Nigeria. Archives of Current Research International, 4(1): 1-10.

Mbulawa S. 2017. Accelerating Agricultural Productivity to Enhance Economic Growth in Botswana. Current Research in Agricultural Sciences, 4(1): 14-31.

Narayan PK. 2005. The saving and investment nexus for China: Evidence from cointegration tests. Applied Economics, 37: 1979-1990.

Njikam O. 2003. Exports and Economic Growth in Sub-Saharan Africa: Is there a Connection? University of Yaounde, Cameroon. 
Noula GA, Gustave LS, Munchunga DG. 2013. Impact of Agricultural Export on Economic Growth in Cameroon: Case of Banana, Coffee and Cocoa. International Journal of Business and Management Review, 1: 44-71.

Nyasulu T. 2013. Assessing the Impact of Exports and Imports on Economic Growth: A Case Study of Malawi from 1970 to 2010. An Unpublished M.Econ Thesis in Development Studies of the Institute of Social Development, Faculty of Economics and Management Sciences, University of the Western Cape.

Ocholi A. 2011. A Comparative Analysis of Performance of Selected Rural Banks in Enhancing Agricultural Development in Nigeria. Unpublished PhD Thesis Submitted to the Department of Agricultural Economics, Federal University of Agriculture, Makurdi.

Odero E. 2017. Analysing the Causal Relationship between Agricultural Value Addition and Economic Growth in Namibia. European Journal of Basic and Applied Sciences, 4(2): 2059-3058.

Ofori G. 2006. Construction Industry and Economic Growth in Singapore. SJE, 6(1): 57-70.

Oje-Okoro I. 2011. Analysis of the Contribution of Agricultural Sector on the Nigerian Economic Development. World Review of Business Research, 1: 191-200.

Perron P. 1997. Further Evidence on Breaking Trend Functions in Macroeconomic Variables. Journal of Econometrics, 80(2): 355-385.

Pesaran M, Shin Y. 1999. An Auto-Regressive Distributed Lag Modeling Approach to Cointegration Analysis. Chapter 11 in Econometrics and Economic Theory in the 20th Century: The Ragnar Frisch Centennial Symposium, Strom S (ed.). Cambridge University Press: Cambridge.

Pesaran M, Shin Y, Smith R. 2001. Bounds Testing Approaches to the Analysis of Level Relationships. Journal of Applied Econometrics, 16: 289-326.

Prebisch R. 1950. The Development of Latin America and its Principal Problems. Lake Success, New York.

Riezman M. 1996. A New Paradigm for Policy Reform and Economic Development. American. Journal of Agricultural Economics, 72(3): 821-826
Rostow WW. 1960. The Stages of Economic Growth: A Non Communist Manifesto. Cambridge University Press.

Sallam MAM. 2014. Analysis and Measurement of the Relationship Between GDP and GFCF: A Comparison Study Between Egypt and Saudi Arabi. Financial and Commercial Research Journal. Port Said University, Faculty of Commerce.

Schultz TW. 1964. Transforming Traditional Agriculture. Chicago, University of Chicago Press.

Solow R. 1957. Technological Change and the Aggregate Production Function. Review of Economics and Statistics, 39(3): 312-320.

Szirmai A. 2009. Industrialization as an engine of growth in developing countries. UNU-MERIT Working Papers.

Tandrayen-Ragoobur V. 2010. The Service Sector and Economic Growth in Mauritius. A Bounds Testing Approach to Cointegration. University of Mauritius Research Journal, 16: 313-331.

Thirtle C, Lin L, Piesse J. 2001. The Impact of Research-led Agricultural Productivity Growth of Poverty Reduction in Asia, Africa and Latin America. IAAE. South Africa.

Tiffin R, Irz X: 2006. Is Agriculture the Engine of Growth? Journal of the International Association of Agriculture Economics, 35(1): $79-89$.

Timmer CP. 1990. Agriculture and Economic Development Revisited. In Paul S. Teng and Fritz W. T. Penning de Vries, (eds). Agricultural Systems, 38(5): 1-35.

Timmer CP. 2003. Food Price Policy: The Rationale for Government Intervention. Food Policy, 14(1): 17 - 29.

TRANSTEC/ BIDPA. 2009. Botswana Agriculture Sector Review. Agricultural Strategy: 2010-2016. Gaborone, Botswana.

World Bank. 2008. World Development Report: Agriculture for Development. The World Bank, Washington DC.

World Bank. 2017. On-line World Development Indicators Database. http://databank.worldbank.org/ddp/home.do, (Accessed - September 2019).

Ziaur R. 2013. Inflation and Economic Growth in Bangladesh: An Empirical Analysis by Using VAR model. Asian Journal of Empirical Research, 4(8): 404-420. 